\title{
Parliamentary Control of the Deployment of Spanish Armed Forces Abroad in the Post-Iraq Era
}

\author{
$B y$ Yolanda GamarRa*
}

\section{Introduction}

From 1989 to 1999 , the participation of the Spanish Armed Forces in international military operations took place within a context of domestic normality and international legality. ${ }^{\mathrm{I}}$ However, the Kosovo crisis ( I 999) prompted controversy, and the intervention in Iraq (2003) saw the breakdown of parliamentary consensus. Spain is not alone in this respect. Abuses committed by United Nations (UN) bodies and the executive branches of western states in the humanitarian interventions in the r 990 os (Somalia and Kosovo) and non-interventions (Rwanda), and the post-9/ I I handling of Afghanistan and Iraq, prompted national and international debates concerning the legality and legitimacy of the use of force in operations outside of national territory and/or Europe. The post-Iraq controversy in Spain reflects similar disagreements in other countries, particularly Britain and the Netherlands.

In Spain, there was strong criticism from the opposition concerning the lack of an ex ante mechanism for parliamentary control over the participation of the Armed Forces in Iraq. ${ }^{2}$ In order to avoid similar

* Professor of Public International Law and International Relations, School of Law, University of Zaragoza (Spain). Email: gamarra@unizar.es. I want to thank Carlos Garrido, Esteban Peralta and Jaime Sanaú for their continuing help and support of this article. I thank the reviewers from the British Yearbook of International Law and especially the editors of the Symposium for their comments and editing suggestions. All URLs are correct as of 30 June $20 \mathrm{r} 8$.

I The list of international operations in which Spain has participated can be found in Y Gamarra, 'The Politics of the Legal Framework governing Spanish Foreign Policy on International Administration in Crisis Areas' in O Korhonen (ed), International Administration of Crisis Areas. Nine National Approaches (KDG Research and Publications 2007) I24-26.

2 See the parliamentary debates on the Kosovo and Iraq crises: I Marrero Rocha, 'El discurso jurídico internacional en los debates del Congreso de los Diputados: los casos de Kosovo y la guerra de Irak' (2005) LVII Revista Española de Derecho internacional 49, and La participación de las Fuerzas Armadas españolas en misiones de paz (Plaza Valdés 2007); and D Liñán Nogueras and J Roldán Barbero (eds), El estatuto jurídico de las Fuerzas Armadas en el exterior (Plaza Valdés 2008). On the use of force see AJ Rodrigo, 'Between traditional rules and new practices: Spanish practice regard the use of armed forces (I990-20I5)' (2015) Spanish YB Int'l L 329. 
situations in future, a mandatory political control mechanism was created in 2005 concerning the timing and legality of the participation of the Armed Forces in international operations. Aside from the balance of forces that is established after each general election, there is a trend towards improving legislative control of foreign policy, the direction of which is the responsibility of the executive power.

This article critically reviews the development and impact of parliamentary control in Spain. Part I outlines the constitutional framework concerning the participation of the Armed Forces in international operations prior to 2005. Part II explores the development and impact of the new political control mechanism created in 2005 on both the authorisation of operations ex ante and the (lack of) budgetary monitoring of operations once they have been initiated. Part III focuses on the effectiveness of parliamentary control and monitoring in influencing both governmental decision-making and legislative and public debate. The article concludes with some thoughts on the scope and limits of parliamentary control and monitoring of military operations outside of Spanish territory.

\section{Constitutional Basis For Military Action}

The Spanish Constitution of 1978 (hereafter, 'Constitution') establishes that the Cortes Generales are the representatives of the Spanish towns, and comprise two Chambers: the Senate and the Congress of Deputies (Parliament). The Congress of Deputies shares the control function with the Senate, except for matters of defence, which fall to the Congress of Deputies. The requirement of political responsibility resides in the Congress of Deputies. ${ }^{3}$

The participation of Spain in international military operations has its constitutional basis in the combination and joint reading of various articles of the Constitution:

- $\quad$ article 8(r), which sets out the mission of the Armed Forces;

- article 63(3), which grants the King the power, on the authorization of the Cortes Generales, to declare war and make peace;

- article 94(I), which requires the authorization of the Cortes Generales prior to the giving of the state's consent to entry into various treaties and agreements, including military treaties;

- $\quad$ article $96(\mathrm{I})$, which provides that validly concluded international treaties, once officially published in Spain, shall be part of the internal legal system; and

\footnotetext{
3 For more information, see JR Montero Gibert and J García Morillo, El control parlamentario (Tecnos I984) 43ff; and J Sole Tura and MA Aparicio, Las Cortes Generales en el sistema constitucional (Tecnos I984).
} 
- $\quad$ article 97, which provides that the Government shall conduct domestic and foreign policy, civil and military administration and the defence of the State.

Article 8(I) of the Constitution establishes that the mission of the Armed Forces (comprising Army, Navy and Air Force) is to guarantee the sovereignty and independence of Spain, and to defend its territorial integrity and the constitutional order. In light of the diverse circumstances in which the Armed Forces have been deployed, ${ }^{4}$ the interpretation of article 8(I) has given rise to a controversy about whether its description of the Armed Forces' mission is exhaustive. ${ }^{5}$

On 24 October 1995 the Congress of Deputies approved a resolution that included the conditions for participation by Spain in operations under the mandate of the UN. ${ }^{6}$ Measures adopted by the United Nations Security Council (UNSC) in accordance with Chapter VII of the UN Charter would be considered directly enforceable in Spanish law. The said resolution also indicated that the participation of Spain in UN peace operations was in keeping with the Constitution. One year later, on I 4 November I 996, and in tandem with Spain's full integration into the military structure of NATO, Parliament approved a resolution concerning a communication by the Government about Spain's participation in the renewed Atlantic Alliance. ${ }^{7}$ It could therefore be inferred that the function of the Armed Forces went beyond that stated in article 8 ( I) of the Constitution.

On 2 I March 2003, the Government authorised the sending of a joint unit of the Armed Forces to Iraq for humanitarian aid, along with units from the Air Force for the defence of Turkey, within the scope of agreements reached in NATO, and subject to a time limit of three months. Spain offered logistical and humanitarian assistance, although the Spanish Armed Forces did not participate in 'open hostilities'. The then President appeared before Parliament on 26 March 2003 to explain the deployment of a fleet to the scene of the conflict for humanitarian purposes. The parliamentary opposition as one rejected the unilateral support offered by the Spanish Government to the British-American coalition. Spanish participation in Iraq did not have either the consensus

4 Today, the functions of the Spanish Armed Forces, like the military forces of many comparable states, are projected in the management of areas in crisis at the international level. On this particular see F López Ramón, 'La evolución democrática de la Defensa Nacional' (2007) 80 Revista Española de Derecho Constitucional I I.

5 L Cotino Hueso, 'La posición de las Cortes en el ámbito militar y de la defensa (Atención particular a la reciente experiencia de la crisis de Kosovo)’ (2000) 9 Corts. Anuario de Derecho Parlamentario 253.

6 Los nuevos retos y la reforma institucional de las Naciones Unidas. Resolution approved by the Congress of Deputies, 24 October 1995, BOCG, Congress of Deputies, V Legislature, Serie E, $n^{\circ}$ I 78, 22 November I 995, I-5. The resolution is of a recommendatory, rather than binding, nature.

7 Resolution on the communication from the Government on the participation of Spain in the renewed Atlantic Alliance, D.S. del Congreso de los Diputados, Pleno y Diputación Permanente, VI Legislature, (I996) 39, I 706. 
of Parliament or of the public. The operation in Iraq exceeded the functions specified in article 8(I) of the Constitution and, insofar as it did not have the mandate of the UNSC, exceeded the operations envisaged in the resolution of 24 October 1995 .

The participation of the Spanish Armed Forces in Iraq might have been legally justified on the basis of article 63(3) of the Constitution. This article gives the King, as head of the Spanish state, the power to declare war and make peace, conditional on the previous authorisation of the Cortes Generales. However, to date, this article has never been invoked to authorise operations abroad. There was no political will to invoke this provision in connection with Iraq, in part because the article includes an obsolete formula for declaring war that is not subject to the limitations of international law.

As can be seen, the Spanish legislative framework grants the President of the Government, and the Government as a whole, broad prerogatives to decide upon the sending of Spanish military forces to operations abroad, within the limitations established in international law and the treaties to which Spain is a party, and those arising from the general political framework.

However, it was argued that there should be some requirement for prior legislative authorisation of military operations abroad. This was grounded in the fact that, in accordance with Chapter III (International Treaties) of Title III of the Constitution, most of the international activity of the state that entails obligations is subject to control by Parliament, even though the Government is responsible for the handling of foreign policy (under article 97). ${ }^{8}$ There are few international obligations, especially within the military scope of the state, that are not controlled by Parliament or that are not subject to control. ${ }^{9}$ Spanish participation in the military operation in Iraq gave rise to a search for a mechanism that would cover this grey area, and determine the role of Parliament in situations like Iraq.

\section{Organic Law 5/2005 On Control and Monitoring}

\section{A. Ex ante control by Parliament}

Post-Iraq debates resulted in Organic Law 5/2005 on National Defence of 17 November 2005 (Organic Law 5/2005). ${ }^{\text {IO }}$ Organic Law 5/2005

8 J García Fernández, 'El control político de las misiones militares en el exterior: derecho internacional y derecho interno’ (2003) 9 Newsletter 27.

9 Article 94(I)(b) of the Constitution states the prior authorisation of military treaties and that the Cortes Generales retain control of 'executive treaties' through the institution of requalification. On the requalification of treaties and the problems raised on this issue, see A Remiro Brotóns, Derecho internacional público. 2. Derecho de los tratados (Tecnos I987) I2 Iff.

ro Boletín Oficial del Estado (BOE), n 275, i 8 November 2005, available at <https://www.boe. es/buscar/pdf/2005/BOE-A-2005-I 8933-consolidado.pdf $>$. This replaced an earlier Organic Law 6/ 
establishes regulations, rules and conditions for the participation of military units beyond Spanish borders, and determines the role of the executive and legislative branches concerning the use of the Armed Forces. It also addresses operations to evacuate Spanish nationals abroad when circumstances of instability place their lives or interests in serious danger. In Organic Law 5/2005, the legislative branch curtailed the latitude of the executive in deploying the Armed Forces abroad by requiring a previous decision by the UN or another regional organisation of which Spain is a member; and insisting on active participation by the Parliament in the decision concerning the sending of Armed Forces abroad.

Article 4(2) of Organic Law 5/2005 establishes that Parliament must give prior authorisation for the participation of the Armed Forces in operations outside the national territory, even where operations fall within article 8 ( I) of the Constitution. This demonstrates the tendency of Parliament to act independently of the Senate in the 'imperfect' Spanish bicameralism.

Article I9 of Organic Law 5/2005 provides that, in order for the Spanish Armed Forces to be able to carry out operations abroad that are not directly related to the defence of Spain or of its national interest, there must be:

I. an express request from the government of the state where the forces are going to operate;

2. authorisation from the UNSC in a resolution that does not contradict or violate the principles of conventional international law that Spain has included in its legal system, in accordance with article 96(I) of the Constitution; or

3. an agreement from an international organisation of which Spain is a member, in particular the EU, NATO, or OSCE.

Article 17 of Organic Law 5/2005 includes a new mechanism for the authorisation of the participation of the Spanish Armed Forces in operations abroad. Article I 7( I) includes the 'prior consultation' and 'authorisation' of all operations carried out abroad that are not directly related to the defence of Spain. The authorisation of Parliament must be obtained before the possible participation of the Armed Forces in international operations. However, article I7(2) provides a special procedure for missions abroad that, in accordance with international commitments, require a prompt and immediate response. In such cases, the prior consultation processes may be carried out through emergency procedures.

I 980 on national defense and military organization. An Organic Law is a law that derives from the Constitution, and that usually regulates fundamental rights and key political structures. In general it is recognised to have a certain superiority over ordinary laws: see X Pons Rafols, 'El derecho internacional, la Constitución española y la Ley Orgánica de la Derfensa Nacional' in H Torroja Matéu (ed), Los retos de la seguridad y la defensa en el nuevo contexto internacional (Universitat de Barcelona 2007) 229. 
The purpose of this provision is to try to avoid criticisms about the slowness of ordinary parliamentary mechanisms, and to attempt to obtain an indirect legal mandate from the Cortes Generales so that it could implement a regulated procedure that details the emergency cases with parliamentary authorisation. ${ }^{\text {II }}$ In any case, and if for reasons of urgency it is not possible to make the prior consultation, article I7(3) requires the Government to submit the decision that it has adopted to Parliament as soon as possible for its authorisation.

Since 2005 , the practice of the executive branch in general terms has consisted of submitting military operations abroad for the prior 'consultation' and 'authorisation' of Parliament, sometimes before the plenary session and sometimes before the Defence Commission. ${ }^{\mathrm{I}}$ The lack of a regulatory procedural practice for the provisions of Organic Law 5/2005 has led to an absence of standard procedure. ${ }^{13}$ With the enormous accumulated practice and in view of the difficulty of reforming the Rules of Procedure (I982), ${ }^{\mathrm{I}}$ perhaps now is the right time to propose the adoption of a parliamentary resolution that would regulate a unique procedure for the authorisation and monitoring of military operations abroad.

In theory, Organic Law 5/2005 provides new constraints on the deployment of Spanish Armed Forces abroad. However, as mentioned above, article I 7 (2) permits the executive branch to request ex post authorisation from Parliament, once the executive branch has ordered the participation of the Armed Forces in an international operation. It seems logical to consider that this provision should be limited to situations which are exceptional, or in which the needs for assistance are acute, although even if such interpretations are adopted, the exception can end up becoming the rule. Article I7(2) has been invoked in the case of the earthquake in Haiti (2010), Operation Odyssey Dawn in Libya (20II), and EUTM Mali (2013), among others (the Libyan operation being the only post-Iraq deployment involving the use of force). Moreover, some deployments (such as military units to provide protection in the construction of an internment centre for immigrants in Mauritania in 2006 , or a $\mathrm{P}_{-3}$ Orion patrol aircraft to the coast of Somalia to prevent pirate attacks in 2008), were not submitted for the prior authorisation of Parliament. It was considered that these were operations carried out under the framework of executive agreements.

I F Following the thesis of J Xuclá i Costa and A M $\mathrm{M}^{\mathrm{a}}$ Pla i Boix, 'La autorización y control parlamentario de las misiones del ejército en el exterior: la falta de un procedimiento común' (2008) 74 Revista de las Cortes Generales 23.

${ }^{12} \mathrm{~V}$ Moret Millás, La autorización de las operaciones en el exterior de las fuerzas armadas: una propuesta de regulación parlamentaria. Premio de Defensa 20I3, "José Francisco Querol y Lombardo" (Ministerio de Defensa 2013) 23-26.

I3 The common procedural element upon which this disparity is based is due to the 'lack of regulatory measures' of articles 3 I (I), points 4 and 5 of the Rules of Procedure. See Xuclá i Costa and Pla i Boix, 'La autorización y control parlamentario', 33.

${ }^{14}$ See RI Rodríguez Magdaleno, La participación de las Cortes Generales en la acción exterior del Estado (I979-2OII) (Congreso de los Diputados 2015) 3 I 3 . 
The Spanish legislative branch still falls short in the monitoring of foreign and defence policy in comparison with other European legislative branches. However, using the authorisation procedure, the legislative branch participates to a certain degree with the executive branch in the job of managing the state's foreign policy. This results in a legal foreign policy that is more democratically integrated and, by extension, to an international law with greater legitimacy. However, in the debates of MPs, references to international law are scarce, shallow, and even ambivalent. Most MPs are not lawyers, and very few are international lawyers. Their arguments are focused on defending the legality of the operation if it has a mandate from an international organisation, in accordance with Organic Law 5/2005. Using the language of the UNSC, the executive persuades the legislature to authorise the deployment of the Armed Forces abroad on a case-by-case basis.

\section{B. Monitoring military action}

Article 18 of Organic Law 5/2005 stipulates that the executive branch shall regularly report to Parliament, within a time period that never exceeds one year, concerning the conduct of Armed Forces operations abroad. In view of the freedom of the Government to decide to send Armed Forces abroad, Organic Law 5/2005 obliges the executive branch to give explanations for sending troops to high-risk areas. Control and monitoring by the legislative branch act as a deterrent to the sending of forces, and in theory minimises the extension of periods of deployment, costs, and mission (where mixed civilian-military forces are sent). It is not always an easy task to justify the presence of the Spanish Armed Forces in places like Afghanistan, Chad, Mali or Iraq, where Spain apparently does not have direct interests.

From 2006 to October 2017 the Minister of Defence made nine appearances before the Defence Commission to inform it about the operations of the Spanish Armed Forces abroad. The sequence of appearances was interrupted on two occasions: once in $20 \mathrm{II}$, due to the holding of general elections and the arrival of a new conservative Government, and once in 2015, because the lack of a majority in the Congress of Deputies stopped the Partido Popular from gaining sufficient votes to form a government. This delayed the appearance of the Minister of Defence by one year, to December 20 I6.

In general, the various political groups maintain a constructive position concerning the obligation to report on the progress and cost of operations in which Spain participates. There is no disagreement on the essential points of defence policy with the main opposition party, regardless of the political ideology of the governing party, although criticism has risen from left-wing MPs concerning the lack of information and transparency regarding the carrying out of various operations. 
In the years when the socialist party governed (2004-II), legal discourse was marked by its 'determinist' and 'eclectic' character. ${ }^{15}$ The discourse was the same as during the first term of the conservative party. There were constant critical voices from representatives of several opposition parties. One MP from the conservative party, Asunción Oltra, condemned the conduct of the Minister of Defence of the socialist group for having approved operations without them appearing to be urgent and without the mandatory parliamentary authorisation under article $\mathrm{I} 7(\mathrm{I})$ of Organic Law 5/2005. ${ }^{16}$

However, the most severe criticisms came from the left. In his various appearances before the Defence Commission, the left-wing MP Gaspar Llamazares Trigo took a critical position concerning the participation of the Spanish Armed Forces in operations abroad. In the first appearance by the Minister of Defence, José Bono, the driving force behind the approval of Organic Law 5/2005, to report on the operations of the Armed Forces abroad, Llamazares recognised the value of the aforementioned law and backed the withdrawal of Spanish troops from Iraq as a 'fundamental' basis of the new foreign policy and of the new policy on the participation of Spanish troops in international operations required for the future. ${ }^{\mathrm{I} 7}$ Llamazares especially expressed his distrust of 'sliding' missions and timeframes that exceeded what the legislative branch had initially authorized. Llamazares called for the Minister to provide more information, and for greater access to both public and restricted information (concerning military intelligence). He stressed an element that had been proposed previously, which was a certain bureaucratic processing of authorisations for troops abroad, as in the case of Somalia. In that case, Llamazares complained, parliamentary authorisation should have been requested before the sending of troops and not after the deployment. ${ }^{\text {I8 }}$

In the appearance of the Minister of Defence on 20 December 20I6, there was a qualitative advance in the information provided. The conservative Minister, María Dolores de Cospedal, included references not only to operations, their limits and successes, and the work of Spain, but also to the total cost in absolute figures of each international operation in which the Spanish Armed Forces were participating. ${ }^{\text {I9 }}$

Questions about the actual cost of Armed Forces operations abroad, and not just the cost that appears in the General State Budget, have been

I5 See Marrero Rocha, 'El discurso jurídico internacional', $74 \mathrm{ff}$.

${ }^{16}$ Appearance of Asunción Oltra Torres, Diary of Sessions of the Congress of Deputies, Defence Commission, VIII Legislature, I 4 March 2006, I5, available at $<$ http://www.congreso.es/public_ oficiales/L8/CONG/DS/CO/CO_509.PDF\#page= I $4>$.

${ }^{17}$ Appearance of Gaspar Llamazares Trigo, Diary of Sessions of the Congress of Deputies, Defence Commission, XI Legislature, I4 March 20I6, I I.

I8 Appearance of Gaspar Llamazares Trigo, Diary of Sessions of the Congress of Deputies, Defence Commission, IX Legislature, io December 2008, I4.

I9 Appearence of María Dolores de Cospedal, Diary of Sessions of the Congress of Deputies, Defence Commission, XII Legislature, 20 December 2016. 
repeated year after year since 2006, when the conservative MP Mardones Sevilla demanded not only information about the political repercussion of sending troops to crisis areas, but also to know the itemised cost of each operation. $^{20}$ This matter was also raised by the centre-liberal party, Unión, Progreso y Democracia (UPyD), on repeated occasions, especially by the MP Irene Lozano Domingo, who discovered the difference between the I 4 million euros budgeted for 2014 in the State General Budget and the final (actual) expenditure of between 600 and 700 million euros. Lozano Domingo thought that the actual expenditure was arbitrary and saw it as an impediment to rigorous budgetary control. ${ }^{2 \mathrm{I}}$ In 20I7, the Minister of Defence forecasts that operations abroad will cost I,063 billion euros, compared to $77 \mathrm{I}$ million euros in $20 \mathrm{I} 6 .^{22}$

Amounts allocated for military operations can be increased up to the sum that covers the respective obligations, ${ }^{23}$ funded against the Budgetary Contingency Fund or against other credits in the non-financial budget. ${ }^{24}$ The Ministry of Finance and Civil Service is empowered to authorise this extra credit. ${ }^{25}$ Diversions have been a constant practice since the first year of participation in international missions and have reached I 53.44\% above the budgeted amount in I996, I 35.42\% in I 999 and $126.99 \%$ in $2003 .{ }^{26}$ Since that year, the practice has been to provide a low initial credit and then increase it, charged against the Contingency Fund to increase credit for operations abroad, and provide additional credit and even extraordinary credit for these types of operations. The margin for budgetary action concerning the costs of operations abroad is not so paradoxical, given that it is Parliament itself that grants full freedom to the executive branch to increase credit, and empowers the Ministry of Finance and Civil Service to authorize the extra credit. Parliament only has information about what this decision means in economic terms when the Minister of Finance and Civil Service issues his quarterly reports about the Contingency Fund. However, the Court of Auditors, ${ }^{27}$ which controls extraordinary and additional credit, as well as increases, transfers and other modifications to budgetary credit, has been critical of this type of conduct. In its 2010 report, it recognised a lack of

\footnotetext{
${ }^{20}$ Appearance of Luís Mardones Sevilla, Diary of Sessions of the Congress of Deputies, Defence Commission, XI Legislature, I4 March 2016, Iо.

2I Appearance of Irene Lozano Domingo, Diary of Sessions of the Congress of Deputies, Defence Commission, X Legislature, I 8 December $2013,20$.

22 See the appearance of the Secretary of State for Defense, Agustín Conde Bajén, Diary of Sessions of the Congress of Deputies, Defence Commission, XII Legislature, 26 April, $2017,3 \mathrm{ff}$.

23 This is contemplated in art 54(I) of Law 47/2003, 26 November 2003, on the General Budget, BOE $n^{\circ} 284,27$ November 2003.

24 Ibid, art 53(3).

25 Ibid, art 62(I).

26 Percentages obtained from the Defense Budget published by the General Directorate of Economic Affairs of the Ministry of Defence.

27 Supreme supervisory body for the accounts of the State's own management and the public sector: see Organic Law 2/I982, I 2 May I982, of the Court of Auditors, BOE nº I 2 I, 2 I May I 982.
} 
quality (irregularity) in the ability of Parliament to control budgetary items used for operations by the Armed Forces abroad. ${ }^{28}$

MPs have also raised questions about the scope of the Parliament's control over operations when these change in nature, depending on the volatile situation on the ground. In 2014, the socialist MP Diego López Garrido asked about one of the key aspects not covered by Organic Law 5/2005, namely: what would the operational control of Spanish troops be? Who would do it? Furthermore, and in a clear reference to the operation in Iraq: what would the status of the forces be? What would the rules of engagement be? What would the risk assessment be? He was here expressing an important concern for the safety of Spanish troops in places like Iraq, the Central African Republic and Lebanon. ${ }^{29}$ The status of forces, and instruments for the protetion of the operation and its members, are often overlooked. All of these questions lead us to think that there is still room to improve the monitoring procedure and, therefore, the transparency of Spanish participation abroad, regardless of its nature.

\section{Effectiveness of Parliamentary Control and Monitoring}

\section{A. Effects of pressure and persuasion on governmental decision-making}

There have been doubts about whether the procedures set out in Organic Law 5/2005 are more about good intentions and less about the verification of compliance with internal regulations and international obligations. ${ }^{3 \circ}$ Control and monitoring procedures must be effective, or the function and usefulness of Parliament would be called into question. In general, parliamentary control has a dual objective: to agree positions (on foreign policy) among the various political groups, and to verify the constitutionality of operations depending on the international commitments that have been made. The monitoring procedure acts through cooperation, dialogue and understanding. In practical terms, the purpose of debates in the Defence Commission, and their public nature, is to dissuade the executive from involving the Spanish Armed Forces in operations with a high risk of human losses. In the long term the effectiveness of this monitoring might be measured by the degree of acceptance by the public of participation of the Spanish Armed Forces in military operations abroad, and the costs and risks this entails.

Parliamentary debates exercise a political and moral pressure, the socalled mobilisation of shame, regarding the decisions of the executive branch. Practice has shown that public debates in Parliament generate

${ }_{28}$ Report available at <http://www.congreso.es/docu/inf_fisc'TC/25 I-5.pdf $>$.

29 Appearance of Diego López Garrido, Diary of Sessions of the Congress of Deputies, Defence Commission, X Legislature, I 7 December 2014, 26.

$3 \circ$ Xuclá i Costa and Pla i Boix, 'La autorización y control parlamentario', Io-I 2 
political and moral pressure on the executive branch and accelerate reforms, and this may help in the correction of practices that are against the Spanish and international law. The public nature of debates in the Defence Commission mobilises the executive branch to reconsider the situation created. The executive branch does not like being criticised by members of the opposition, because it represents a major loss of face to the Spanish public and affects international public opinion.

Therefore, in situations of doubtful constitutionality and the violation of international law, in particular international humanitarian law, the executive branch is forced to provide explanations for its actions and a domestic political game is created that the parties in power do not like very much. ${ }^{3 \mathrm{I}}$ Legal doctrine warns that, if the executive branch shares the power to decide and control the use of force with other bodies, the joint action of these bodies ends up affecting the electoral impact and tends to support Parliament as the place where responsibility should be demanded. ${ }^{32}$

In appearances in 20I2 and 20I4, the Defence Minister Pedro Morenés Eulate, from the conservative party, defended Spanish participation in operations abroad to guarantee the security of Spain, world stability, national reliability and credibility, and even defended the Spanish presence in certain crisis areas for 'the good of the global economy'. ${ }^{33}$ According to the Minister, Spanish participation in international operations was helping to make the world both safer and more economically stable. A leftist representative, Centella Gómez, on the other hand, asserted that Spanish participation in international operations militarises policies of cooperation, removes resources allocated to mutual, civic cooperation, and does not always help to make the world safer and more stable. ${ }^{34}$ In the end, there was a debate regarding the change that the concept of defence versus safety had undergone in recent decades.

In general terms, however, there is an agreed continuity regarding Spanish participation in international operations, provided that Spain operates in accordance with the Constitution and domestic law, as well as with international law and, in particular, with international humanitarian law.

Debates by MPs concerning the intervention in Libya-the only postIraq operation that has required the use of force-took place after the sending of the Spanish Armed Forces to the zone of operations. On 22 March 20II, the plenary session of Parliament authorised Spanish

3 I B Russett and J Oneal, Triangulating Peace: Democracy, Interdependence and International Organizations (Norton 201 I) 54 .

${ }^{2}$ H Hänggi, 'The use of force under International auspices: parliamentary accountability and "democratic deficits"' in H Born and H Hänggi (eds), The 'Double democratic deficit'. Parliamentary accountability and the use of force under International auspices (Ashgate 2004) 3.

33 Appearance of Pedro Morenés Eulate, Diary of Sessions of the Congress of Deputies, Defence Commission, X Legislature, I6 May 2012, 26.

34 Appearance of José Luis Centella Gómez, Diary of Sessions of the Congress of Deputies, Defence Commission, X Legislature, i6 May 2012, I 8. 
participation in the international intervention in Libya just five days after the executive branch had approved and deployed military capabilities. This circumstance was no accident, given that, as there were certain similarities between the intervention in Libya and Iraq, the executive branch avoided an embarrassing situation (and political damage). The President attended the plenary session. Of the 340 MPs present, only three voted against and one abstained due to an error. The socialist President, José Luis Rodríguez Zapatero, insisted on the obligation of Spain to contribute to compliance with international law by following UNSC resolutions I970 (201 I) and I973 (201 I).

This position had its supporters and critics. On the one hand, the then leader of the conservative group in the opposition, Mariano Rajoy, approved the decision of the President to involve Spain in the "war in Libya'. However, he warned of the risk that the conflict could result in a prolonged civil war. ${ }^{35}$ On the other hand, Llamazares, a long-standing critic of military operations, stated that at that time there were over thirty conflicts with very similar characteristics to the war in Libya, with despotic Governments that were exterminating part of their own people and, exceptionally, in this specific case, the international community was imposing a war as a solution..$^{36}$ The MP stated that the operation represented the beginning of a new phase of international politics, in which zones of interest were divided up with the support of some and the consent or abstention of others. ${ }^{37}$

In the debates in Parliament regarding the authorisation of the operation, and reports on its progress, there was no questioning of international law. Rather, it was assumed that anything approved within the institutional frameworks of the UN, NATO or the EU was valid. ${ }^{38}$ The parliamentary debate concerning the intervention in Libya, like the others, was formally respectful of international law (legality) and the responsibility to protect $\left(\mathrm{R}_{2} \mathrm{P}\right)$ (legitimacy) without much criticism about the effects of interventions on international law.

The public debates of the Defence Commission facilitate access to general, descriptive information about the international operations in which Spain actively participates. However, there is no accurate and clear information about the progress of Spanish participation in crisis areas concerning what functions troops carry out at the beginning and in later stages, if there are changes in the nature of the operation, what State project is being defended, and the expected time horizon for operations, among other important questions. The discourses of MPs lack coherent analysis and foundations in international law.

35 Diary of Sessions of the Congress of Deputies. Pleno y Diputación Permanente, IX Legislature, $\mathrm{n}^{\circ}$ 232, March $201 \mathrm{I}, 6$.

36 Ibid, Io.

37 See the appearance of Gaspar Llamazares, Diary of Sessions of the Congress of Deputies, Pleno y Diputación Permanente, IX Legislature, $\mathrm{n}^{\circ}$ 232, sesión plenaria $\mathrm{n}^{\circ}$ 220, 22 March 20 I I.

$3^{8}$ Following the thesis of Marrero Rocha, 'El discurso jurídico internacional', 86. 


\section{B. Public debates and public opinion: implications for legislative measures}

Public opinion broadly accepts Spanish participation in legal and legitimate international operations. Specifically, it has not manifested feelings against Spanish participation in the management of crisis areas, with the exception of the Spanish Armed Forces in the intervention in Iraq. Even when a loss of human lives has unfortunately occurred, as in the $Y a k-42$ air crash which killed 62 Spanish peacekeepers returning from Afghanistan, public opinion has supported the hard work of the Spanish Armed Forces and has penalised, where appropriate, the poor handling of the executive branch's defence policy.

From a global point of view, opinion surveys and polls have recorded a high approval rating for said operations. ${ }^{39}$ There is increasingly greater willingness and ability among European citizens to distinguish the nature of some operations (preventive, humanitarian, observation, among others) from others (coercive). Considering the 'feeling' (opinion) of the Spanish public and the course of international dynamics, the executive branch has chosen to strengthen operations within the framework of the EU and NATO.

The Transatlantic Trends report (2013) includes the fact that the Spanish public is in favour of an increasing commitment by the EU in the handling of international crises. ${ }^{40}$ Opinion polls show an unequivocal support of European people, and in turn, an even greater willingness by the Spanish for Armed Forces to participate in the handling of crisis areas, provided that they have the consent of the Government of the state in crisis and that the participation is preventive, humanitarian or concerning election monitoring, and is carried out in accordance with international law.

The acceptance of an operation changes, however, when the participation is in military operations that require the use of force, or entail a high risk to human lives. The Spanish public supports development cooperation policies, aid operations for natural disasters, the establishment of peace, respect for human rights and international humanitarian law, and actions against terrorism, among other operations, but is reluctant for Spain to become involved in military operations that require the use of armed force. A survey carried out in January 2016 by the Real Instituto Elcano revealed that $5 \mathrm{I} \%$ of Spanish people supported Spanish participation in international operations and $42 \%$ did not. ${ }^{4 \mathrm{I}}$ From said percentages it can be deduced that public opinion is polarised, due to the perception of a serious risk and threat to Spanish troops represented by

39 See the approach of AL Alonso de Antonio, 'Dimensión constitucional de la nueva Ley Orgánica de Defensa Nacional’ in Estudios sobre la Constitución Española. Homenaje al profesor Fordi Solé Tura (Cortes Generales 2009) vol I, 297.

40 Transatlantic Trends, available at <http://www.gmfus.org/publications/transatlantic-trends-20 $3>$.

${ }_{4 \mathrm{I}}$ Barómetro del Real Instituto Elcano (BRIE), January, 20I6, 22. Information available at $<\mathrm{http}: / /$ www.realinstitutoelcano.org/wps/portal/rielcano_es/encuesta?WCM_GLOBAL_CONTEXT=/elcano/ elcano_es/barometro/oleadabrie37>. 
operations against international terrorism and, in particular, against the Islamic State.

In addition to pressure from public debates in the Defence Commission, there is also pressure from other actors in civil society, such as the media, think-tanks, foundations, lobbying groups and notfor-profit associations. ${ }^{42}$ Awareness campaigns increasingly help to condition the executive branch in its foreign policy, to prioritise certain fora (formal and informal), scenarios (high or low intensity), and certain contexts (piracy, the protection of human rights or the fight against terrorism).

Public debates in Parliament about Spanish foreign and defence policy, and the involvement of the public in these subjects, have had the effect of specific legislative measures in the military field. The interest of the public in guaranteeing the security of Spanish Armed Forces in operations abroad has facilitated the passing of a series of laws, such as Organic Law 9/20I I, on the rights and duties of members of the Armed Forces; ${ }^{43}$ Organic Law I I/2007, which regulates the rights and duties of members of the Guardia Civil $;{ }^{44}$ the updating of the new Military Penal Code in Organic Law $14 / 2015 ;{ }^{45}$ and the Disciplinary Code of the Armed Forces in Organic Law 8/2014. ${ }^{46}$

\section{Conclusions}

Criticisms of the participation of Spanish military forces in the interventions in Kosovo and Iraq produced a new legislative framework for deployment of the Armed Forces abroad. From 2005-I 7, Spanish military operations have complied with both international and domestic legality. In the case of Libya, the only operation that has required the use of force, respect for the resolutions of the UNSC and the authorisation of Parliament ensured that Spanish participation was in compliance with international and domestic legality, at the same time as demonstrating the legitimacy of said actions. There are some significant blots on such an affirmation, however. On the one hand, the fact that the operation was authorised only once the Spanish Armed Forces had been deployed on the ground produced questions and criticisms about the usefulness of the

42 See on the relationship of public opinion and use of force L Klaveras, 'The "Essential Domino" of military operations: American public opinion and the use of force' (2002) International Studies Perspectives 4I 7 .

43 Organic Law 9/20I I, 27 July 20I I, on the rights and duties of members of the Armed Forces, BOE $n^{\circ}$ i 80,28 July 20 I .

44 Organic Law I I/2007, 22 October 2007, regulating the rights and duties of the members of the Civil Guard, BOE $\mathrm{n}^{\circ} 254,23$ October 2007.

45 Organic Law I4/20I5, of I4 October 20I5, of the Military Penal Code, BOE n ${ }^{\circ} 247$, I 5 October 2015 .

${ }^{4} 6$ Organic Law 8/20I4 of 4 December 2014 of the Disciplinary Regime of the Armed Forces, BOE, $n^{\circ} 294,5$ December 2014 . 
law and parliamentary control itself. The use of ex post facto authorization may effectively disable parliamentary control. On the other hand, the Parliament, even in offering ex post facto authorisation, may be playing some role in a larger development of the law. For example, in invoking the responsibility to protect, it may be contributing to a process of changing the law on war.

Practice shows that the monitoring procedure under Organic Law $5 / 2005$ has been frustrated by the timing of engagements and the lack of access to relevant information. Also, the international legal situation has left the contents of Organic Law 5/2005 out of date. New international dynamics, new threats and new public demands for transparency and control require a new law that will (re)define the functions of Armed Forces in operations abroad. Nevertheless, the Organic Law is a significant step in the democratization of Spain's defence policy.

As is the case in other European democracies, parliamentary control over the foreign policy of the executive branch concerning defence must move towards a consensual model. It did not seem logical that, in an advanced democracy, the executive branch could have the freedom to decide on the use of Armed Forces without the prior authorisation of Parliament. The purpose of Organic Law 5/2005 is to achieve a more participative, transparent democracy that is close to the interest of the public. In a subject as sensitive as the sending of troops to areas in crisis, Spanish politicians should continue to work to achieve a consensus concerning a matter that is traditionally agreed to uphold the credibility of the executive branch and, above all, the work and professionalism of the Spanish Armed Forces themselves. However, more information on various matters-operational, economic, legal, among others-and more accurate information at all times and under all circumstances, would be an indication of transparency that would strengthen democratic control. 